\title{
Nasal mucociliary clearance in chronic renal failure: Comparision of pre-dialysis and dialysis stages
}

\section{Kronik böbrek yetmezliğinde nazal mukosiliyer klirens: Diyaliz öncesi ve diyaliz dönemlerinin karşılaştırılması}

\author{
Sinan ULUYOL ${ }^{1}$, Alper ALP ${ }^{2}$, Saffet KILICASLAN ${ }^{1}$, Mehmet Hafit GUR ${ }^{1}$ \\ ${ }^{1}$ Van Ĕ̆itim ve Araştırma Hastanesi, Kulak Burun Boğaz, Kliniğ i, Van \\ ${ }^{2}$ Van Ĕ̆itim ve Araştırma Hastanesi, Nefroloji Kliniği, Van
}

\begin{abstract}
Objective: Chronic renal failure (CRF) is an irreversible condition that has many otorhinolaryngological manifestations. In this study we aimed to investigate the effects of CRF and haemodialysis treatment on nasal mucociliary clearance (MCC) and to explain the possible pathophysiological mechanisms.

Methods: This study included 27 patients with end-stage CRF who were not undergoing haemodialysis (pre-dialysis group), 36 patients with CRF on haemodialysis (dialysis group), and 36 heathy individuals. Nasalmucociliary clearance was measured using the saccharin clearance test (SCT) and the results were statistically compared among the three groups.

Results: Mean SCT times in the control, pre-dialysis, and dialysis groups were $11.7 \pm 5.7,30.16 \pm 11.66$, and $27.33 \pm 9.4 \mathrm{~min}$, respectively. The results for both the predialysis and dialysis groups were significantly higher when compared with the control group (both $\mathrm{p}<0.001$ ). There was no significant difference between the pre-dialysis and dialysis groups $(\mathrm{p}=0.22)$.

Conclusion: Both CRF and haemodialysis treatment cause severe prolongation of MCC time. Patients with CRF should be monitored closely for middle ear, sinonasal, and respiratory tract infections and informed about potential risks of infection.
\end{abstract}

Key words: Chronic renal failure, dialysis, infection, mucociliary clearance, saccharin

$\ddot{\mathbf{O Z Z}}$

Amaç: Kronik böbrek yetmezliği (KBY), kulak burun boğaz açısından birçok klinik bulgu oluşturan ve geri dönüşü olmayan bir durumdur. Bu çalışmada, KBY'nin ve hemodiyaliz tedavisinin nazal mukosiliyer klirens üzerine etkisinin araştırılması ve olası patofizyolojik mekanizmaların açıklaması amaçlanmıştır.

Yöntemler: Bu çalışmaya, son dönem KBY olan ve diyaliz tedavisi almayan 27 hasta (pre-diyaliz grup), son dönem KBY olan ve diyaliz tedavisi almakta olan 36 hasta (diyaliz grubu) ve 36 sağlıklı birey (kontrol grubu) dahil edildi. Nazal mukosiliyer klirens ölçümü sakkarin klirens testi kullanılarak ölçüldü ve sonuçlar üç grup arasında istatistiksel olarak karşılaştırıldı.

Bulgular: Ortalama sakkarin klirens testi zamanı kontrol, pre-diyaliz ve diyaliz gruplarında sirasiyla $11,7 \pm 5,7,30,16 \pm 11,66$ ve $27,33 \pm 9,4$ dk. olarak bulundu. Prediyaliz ve diyaliz gruplarında, her iki grup için elde edilen sonuç kontrol grubuna göre anlamlı ölçüde yüksekti (her iki $\mathrm{p}<0,001$ ), pre-diyaliz ve diyaliz grupları arasında anlamlı fark saptanmadı $(\mathrm{p}=0,22)$.

Sonuç: Hem KBY hem de hemodiyaliz tedavisi nazal mukosiliyer klirens zamanında ciddi uzamaya neden olmaktadır. Bu nedenle KBY olan hastalar orta kulak, sinonazal veya solunum yolu enfeksiyonları açısından yakından takip edilmeli ve olası enfeksiyon risklerine karşın bilgilendirilmelidirler.

Anahtar kelimeler: Diyaliz, enfeksiyon, kronik böbrek yetmezliği, mukosiliyer klirens, sakkarin

Alındığı tarih: 05.01.2016

Kabul tarihi: 19.04 .2016

Yazışma adresi: Uzm. Dr. Sinan Uluyol, Van Bölge Eğitim ve Araştırma Hastanesi, 65030 Van e-mail: sinanuluyol@hotmail.com 


\section{INTRODUCTION}

Chronic renal failure (CRF) is defined as the inevitable damage and destruction of nephrons and a reduction in glomerular filtration rates resulting in chronic, progressive deterioration of the liquidelectrolyte balance ${ }^{(1,2)}$. CRF is an irreversible condition with multiple aetiologies that may lead to many physiological, haematological, metabolic, endocrine, cardiovascular, and respiratory system problems ${ }^{(3,4)}$.

Mucociliary clearance (MCC) is the primary defence mechanism in the respiratory system against noxious inhaled materials ${ }^{(5)}$. MCC occurs via the synchronised movement of cilia in the respiratory tract in a manner that propels mucus and other substances trapped within the mucus towards the pharynx to be swallowed ${ }^{(6)}$. In healthy individuals, MCC typically works effectively. However, a variety of systemic factors alter mucociliary activity, including diabetes mellitus ${ }^{(7)}$, hypertension ${ }^{(7)}$, and hypothyroidism ${ }^{(8)}$.

Although CRF has a multifactorial systemic effect, its effect on MCC has received little attention. Therefore, we examined the effects of CRF and haemodialysis on MCC using the saccharin clearance test (SCT) and aimed to explain the possible pathophysiological mechanisms.

\section{MATERIALS and METHODS}

This study adhered to the guidelines of the Helsinki Declaration of the World Medical Association and was approved by the research ethics committee of a tertiary referral centre (no. 2015/38). Written informed consent was obtained from all participants before the study.

A total of 27 patients with end-stage CRF who were not undergoing haemodialysis comprised the pre-dialysis group; and 36 patients with CRF on haemodialysis comprised the dialysis group, and 36 heathy individuals were recruited as the control group. Patients with diabetes mellitus, cystic fibrosis, hypertension, hypothyroidism, nasal septum deviation, allergic rhinitis, and sinonasal infections, and smokers were excluded from the study .

The saccharin clearance test (SCT) was used to measure MCC. The SCT involves placing $5 \mathrm{mg}$ (1/4 tablet) of saccharin behind the anterior edge of the inferior turbinate at the same location in all patients. The result was measured as the time (min) required for the patient to perceive the taste of saccharin. One researcher performed all of the SCTs.

The SCT times were compared statistically using SPSS for Windows software (ver. 20.0; SPSS, Chicago, IL, USA). Continuous variables were presented as means \pm standard deviation and categorical variables were presented as percentages. Qualitative values were compared using the chi-square test. The significance of different SCT times among the predialysis, dialysis, and control groups was evaluated using analysis of variance (ANOVA). The Spearman correlation coefficient (r) was used to analyse the correlation of SCT time with disease duration in predialysis and dialysis groups. A p-value of $<0.05$ was taken to indicate statistical significance.

\section{RESULTS}

The pre-dialysis group included 27 patients (15 females, 12 males) with a mean age of $41.17 \pm 12.32$ years (range: 17-59 years). The dialysis group included 36 patients ( 21 females, 15 males) with a mean age of $38.55 \pm 10.74$ years (range: $21-64$ years). The control group included 36 healthy subjects (20 females, 16 males) with a mean age of $40 \pm 13.96$ years (range: 18-55 years). The age and sex distributions of the patients did not differ significantly among the groups.

The mean duration of CRF was $5.18 \pm 2.33$ years (range: 2.1-8.5 years) in the pre-dialysis group and $17.18 \pm 5.33$ years (range: $3.8-31.3$ years) in the dialysis group. The duration of CRF time was significantly greater in the dialysis group $(\mathrm{p}=0.013)$. The mean duration of haemodialysis was $10.52 \pm 5.3$ years (range: 4-30 years).

The mean SCT time was significantly greater in the pre-dialysis and dialysis groups compared to the 
controls (pre-dialysis: $30.16 \pm 11.66$ vs. $11.7 \pm 5.7 \mathrm{~min}$, respectively, $\mathrm{p}<0.001$; dialysis: $27.33 \pm 9.4$ vs. $11.7 \pm 5.7 \mathrm{~min}, \mathrm{p}<0.001)$. Although the SCT time was higher in the pre-dialysis group, it was not significantly different from the dialysis group $(30.16 \pm 11.66$ vs. $27.33 \pm 9.4 \mathrm{~min}$, respectively, $\mathrm{p}=0.22$ ). Table 1 presents the SCT times. There was a negative correlation between the SCT time and disease duration between the pre-dialysis and dialysis groups $(\mathrm{r}=-0.712$, $\mathrm{p}=0.016)$.

Table 1. SCT times.

\begin{tabular}{lccccc}
\hline & $\begin{array}{c}\text { Control } \\
\text { Group } \\
(\mathbf{n = 3 6 )}\end{array}$ & $\begin{array}{c}\text { Pre-dialysis } \\
\text { group } \\
(\mathbf{n = 2 7})\end{array}$ & $\mathbf{p}^{*}$ & $\begin{array}{c}\text { Dialysis } \\
\text { group } \\
(\mathbf{n = 3 6})\end{array}$ & $\mathbf{p}^{* *}$ \\
\hline SCT (range) & $6.3-16.6$ & $9.5-48.8$ & & $9.3-60$ & \\
SCT (min) & $11.7 \pm 5.7$ & $30.16 \pm 11.66$ & $<0.001^{\mathrm{a}}$ & $27.33 \pm 9.4$ & $<0.001^{\text {a }}$
\end{tabular}

$S C T$, saccharin clearance test; $C R F$, chronic renal failure. ${ }^{a}$ analysis of variances.

*analysis between control group and pre-dialysis group.

**analysis between control group and dialysis group.

\section{DISCUSSION}

Mucociliary clearance is a vital respiratory system defence mechanism. The ability of respiratory mucosal surfaces to eliminate foreign particles and pathogens and to keep mucosal surfaces moist and fresh depends on mucociliary activity. Effective MCC requires appropriate mucus production, coordinated ciliary activity, and the mucus-cilia interaction. Cilia line the nasopharynx, middle ear, paranasal sinuses, and tracheobronchial airways; therefore, any disturbance in MCC leads to the stagnation of secretions and recurrent middle ear, sinonasal, and lower respiratory tract infections ${ }^{(5,9-11)}$. There are two main causes of MCC impairment: impaired ciliary function or mucus structure and movement ${ }^{(12,13)}$.

Chronic renal failure is a pathophysiological process that is associated with enhanced oxidative stress, hypoxia, and endothelial dysfunction ${ }^{(14)}$. Oxidative stress is the imbalance between the generation of reactive oxygen species (ROS) and anti-oxidative defence mechanisms. Renal toxicity, immunological disorders, ischemia and reperfusion result in the ele- vated production of ROS, which are active in the pathogenesis of endothelial dysfunction ${ }^{(15,16)}$. The primary pathological changes of endothelial dysfunction occur in small vessels or capillaries and result in capillary vasoconstriction, rarefaction, and limited oxygen diffusion, and decreased microcirculatory blood flow leads to chronic cellular hypoxia, which is associated with the pathogenesis of end-organ damage $^{(17,18)}$.

Our results do not fully explain the molecular mechanisms of the prolonged SCT times and MCC damage during CRF or haemodialysis treatment, but we speculate that ciliary movements are affected directly by the formation of free oxygen radicals or uremic toxins with resultant damage to dynein arms and microtubules. Endothelial dysfunction and vasoconstriction reduce blood flow and might also decrease periciliary blood flow and cause hypoxia in the cilia. Liquid-electrolyte imbalance or deterioration of glandular tissues by uremic toxins or oxidative stress can lead to an increase in mucus viscosity, rendering ciliary clearance ineffective. Furthermore, as supported by studies by Fahy and Dickey, an increase in mucus viscosity can cause the periciliary liquid layer to shrink, resulting in the cilias being squeezed underneath the mucus layer which also blocks their movement ${ }^{(19)}$. Previously, nasal biopsies of CRF patients revealed chronic inflammation and metaplasia of the epithelium with thin-walled vessels and extensive fibrosis ${ }^{(20)}$.

To date, only one study evaluated MCC during haemodialysis treatment ${ }^{(21)}$ using the SCT to compare a group of dialysis patients with healthy controls and found a significant difference in MCC $(12.51 \pm 3.74$ vs. $8.97 \pm 1.83 \mathrm{~min})$. In that study, the mean disease duration was $6.38 \pm 6.74$ years (range: 1-29 years). Our study also assessed pre-dialysis patients. The MCC was significantly higher in both the pre-dialysis and dialysis groups than in the controls. Although the duration of disease was much shorter in the predialysis group than in the dialysis group, the MCC time was paradoxically higher. These findings suggest that haemodialysis reduces the effects of CRF on 
mucociliary dysfunction. This phenomenon might be explained by haemodialysis which filters toxins and oxidants and shifts the liquid-electrolyte balance favourably.

In conclusion, $\mathrm{CRF}$ causes severe prolongation of the MCC time. The clinical significance of this effect is of concern in terms of middle ear, sinonasal, or respiratory tract infections. Patients with CRF or those undergoing haemodialysis should be monitored more closely and informed about the possible susceptibility to infections. This study suggests that haemodialysis might have shorten CRF-induced mucociliary clearance. Further studies will be necessary to elucidate the exact mechanism.

The strength of our study is the evaluation of both pre-dialysis and dialysis patients for the first time. However, the small sample size limits its interpretation and generalisability. The main limitation is the lack of clinical follow-up data on respiratory tract, middle ear, and sinonasal infections. Such information could determine the association between the possible side effects of CRF-related MCC impairment and relevant morbidities.

\section{REFERENCES}

1. Gokal R, Hutchison A. Dialysis therapies for end-stage renal disease. Semin Dial 2002;15:220-226. http://dx.doi.org/10.1046/j.1525-139X.2002.00064.x

2. Kaysen GA, Eiserich JP. Characteristics and effects of inflammation in end-stage renal disease. Semin Dial 2003;16:438-446. http://dx.doi.org/10.1046/j.1525-139X.2003.16096.x

3. Ronco C, House AA, Haapio M. Cardiorenal syndrome: refining the definition of a complex symbiosis gone wrong. Intensive Care Med 2008;34:957-962. http://dx.doi.org/10.1007/s00134-008-1017-8

4. Young DO, Lund RJ, Haynatzki G, Dunlay RW. Prevalence of the metabolic syndrome in an incident dialysis population. Hemodial Int 2007;11:86-95. http://dx.doi.org/10.1111/j.1542-4758.2007.00158.x

5. Munkholm M, Mortensen J. Mucociliary clearance: pathophysiological aspects. Clin Physiol Funct Imaging 2014;34:171177. http://dx.doi.org/10.1111/cpf.12085

6. Wanner A, Salathé M, O'Riordan TG. Mucociliary clearance in the airways. Am J Respir Crit Care Med 1996;154(6 Pt 1):1868-1902. http://dx.doi.org/10.1164/ajrccm.154.6.8970383
7. de Oliveira-Maul JP, de Carvalho HB, Miyuki Goto D, Mendonça Maia R, Fló C, Barnabé V, et al. Aging, diabetes, and hypertension are associated with decreased nasal mucociliary clearance. Chest 2013;143:1091-1097. http://dx.doi.org/10.1378/chest.12-1183

8. Uysal IO, Gökakın AK, Karakuş CF, Deveci K, Hasbek Z, Sancakdar E. Evaluation of nasal mucociliary activity in iatrogenic hypothyroidism. Eur Arch Otorhinolaryngol 2013;270:3075-3078. http://dx.doi.org/10.1007/s00405-013-2439-7

9. Yazici H, Soy FK, Kulduk E, Doğan S, Dündar R, Sakarya EU, et al. Comparison of nasal mucociliary clearance in adenoid hypertrophy with or without otitis mediawith effusion. Int J Pediatr Otorhinolaryngol 2014;78:1143-1146. http://dx.doi.org/10.1016/j.ijporl.2014.04.037

10. Antunes MB, Cohen NA. Mucociliary clearance-critical upper airway host defense mechanism and methods of assessment. Curr Opin Allergy Clin Immunol 2007;7:5-10. http://dx.doi.org/10.1097/ACI.0b013e3280114eef

11. Vlastos I, Athanasopoulos I, Mastronikolis NS, Panogeorgou $\mathrm{T}$, Margaritis V, Naxakis S, et al. Impaired mucociliary clearance in allergic rhinitis patients is related to a predisposition to rhinosinusitis. Ear Nose Throat J 2009;88:E17-19.

12. Knowles MR, Boucher RC. Mucus clearance as a primary innate defense mechanism for mammalian airways. J Clin Invest 2002;109:571-577. http://dx.doi.org/10.1172/JCI0215217

13. Lale AM, Mason JD, Jones NS. Mucociliary transport and its assessment: a review. Clin Otolaryngol Allied Sci 1998;23:388-396. http://dx.doi.org/10.1046/j.1365-2273.1998.00173.x

14. Annuk M, Zilmer M, Lind L, Linde T, Fellström B. Oxidative stress and endothelial function in chronic renal failure. $J$ Am Soc Nephrol 2001;12:2747-2752.

15. Galle J. Oxidative stress in chronic renal failure. Nephrol Dial Transplant 2001;16:2135-2137. http://dx.doi.org/10.1093/ndt/16.11.2135

16. Miyata T, Wada Y, Cai Z, Iida Y, Horie K, Yasuda Y, et al. Implication of an increased oxidative stress in the formation of advanced glycation end products in patients withend-stage renal failure. Kidney Int 1997;51:1170-1181. http://dx.doi.org/10.1038/ki.1997.160

17. Galle J, Quaschning T, Seibold S, Wanner C. Endothelial dysfunction and inflammation: what is the link? Kidney Int Suppl 2003;(84):S45-49. http://dx.doi.org/10.1046/j.1523-1755.63.s84.12.x

18. Ece A, Gurkan F, Kervancioglu M, Kocamaz H, Güneş A, Atamer Y, et al. Oxidative stress, inflammation and early cardiovascular damage in children with chronic renal failure. Pediatr Nephrol 2006;21:545-552. http://dx.doi.org/10.1007/s00467-006-0039-0

19. Fahy JV, Dickey BF. Airway mucus function and dysfunction. N Engl J Med 2010;363:2233-2247. http://dx.doi.org/10.1056/NEJMra0910061

20. Mitschke H. Otorhinolaryngological diseases in patients with advanced kidney failure after kidney transplantation. Fortschr Med 1980;98:437-440.

21. Kucur C, Ozbay I, Gulcan E, Kulekci S, Aksoy S, Oghan F. Evaluation of nasal mucociliary activity in patients with chronic renal failure. Eur Arch Otorhinolaryngol 2016;273:1167-1171. http://dx.doi.org/10.1007/s00405-015-3712-8 